\title{
Opinions differ on spending NIH gold
}

Differences within the US research community over how best to support biomedical research create the impression of factional quarrelling. That cannot be avoided, but it would help if there were a director of the NIH in post.

THE annual budget of the US National Institutes of Health $(\mathrm{NIH})$, now more than $\$ 8,000$ million a year, is the largest single source of support for basic research in the whole wide world. This pot of gold, steadily enlarged over four decades, has created and sustained the US biomedical research community, which is the most productive research community anywhere. Yet there are now sharp divisions of opinion among researchers about the way in which the NIH budget is spent. One issue, raised by a report from the Institute of Medicine last month, is whether more should go on infrastructure (buildings and equipment) and on training in research. Another, not as clearly articulated, is that of the correct balance between research aimed at the improvement of known therapies and the search for radically new methods of treating or avoiding disease, notably those offered by modern molecular and cell biology.

These are not academic issues. Even if the NIH budget were infinite, the future pattern of medicine would still be determined by the present distribution among research fields of the limited stock of able people. But the budget, although increased by nearly $\$ 1,000$ million above the administration's request for the current year, is far from infinite. And resentment persists that, in the financial year to last October, there were fewer new research grants than in any year since 1977 , and that the chance that a technically competent research proposal would be funded had fallen to less than a quarter. But the NIH budget is also constrained internally (by NIH's in-house commitments) and externally by the increasingly specific conditions attached by the US Congress to its allocations of funds, generous though they may be. This year, for example, NIH have been asked to increase the number of new research grants to 6,000 .

There will be unwelcome consequences if it is left to the Congress to decide between these (and other) legitimately competing views of how NIH should spend their money. Last month, the Federation of American Societies of Experimental Biology went out of its way to reject the Institute of Medicine's plea on behalf of the infrastructure of biomedical research. Meanwhile, the American Society of Cell Biology, although keen that there should be more research grants, has been pressing that the promise of the new biology should be given more attention (see Nature 348, 270; 1990).

The obvious danger is that lobbying, successful or otherwise, will tempt the Congress to determine not just the scale, but the details, of NIH spending. The growth of the NIH budget so far owes much to the touching faith of the Congress that more research means better health. Congressional committees have mostly allowed the research community to make its own judgements on the spending of public funds, confining their enquiries to administrative matters (such as the effectiveness of peerreview) and the good sense of major initiatives (such as the Human Genome Project). But the Congress could in principle take to offering opinions on the merits of certain kinds of research proposals. It has a constitutional right to a view on the infrastructure question, and on the potential benefits for health care of modern molecular and cell biology. But deciding these questions in isolation would be dangerous.

The best course would be that the long hiatus in the appointment of a director of NIH should be ended quickly, and that the new administration should undertake the long-overdue policy appraisal that would both carry weight with the research community and assure the Congress that the world's biggest fund for basic research is being spent wisely and effectively. In everybody's interests, it is important that two nettles should be firmly grasped. First, there is the running sore of what are called "indirect costs" — the overhead charges paid to institutions in receipt of research grants. The second nettle is the balance between in-house and extramural spending. To raise the question now is not to suggest that the present balance is wrong, but merely to remark that the question has not been asked, or answered, for a long time.

\section{Regional restraints}

The ending of the Cold War seems to have revived interest in regional arms control arrangements.

THE governments of Argentina and Brazil have been blazing an interesting trail in the past few weeks. First, the newly elected president of Brazil ceremonially emptied the first shovel-full of rubble into a hole in the ground said to have been intended (by a secret agency of the previous government) for an underground nuclear explosion. Now Argentina and Brazil have jointly forsworn the development of nuclear weapons, but have also declared that 